\title{
HEJKUM GEJKUM?
}

\author{
Piotr Sobolczyk \\ Instytut Badań Literackich PAN
}

\begin{abstract}
Artykut jest reinterpretacja stynnego i kultowego polskiego filmu Kingsajz, powszechnie uważanego za alegorie polityczną. Film ten można jednak odczytać także queerowo jako wypowiedź nt. reżimów genderowych. Zinterpretowano tu liczne aluzje homoerotyczne. Istotne jest także pytanie o dominujacy w kulturze polskiej kod odbiorczy polegający na uprzywilejowywaniu odczytań politycznych względem innych możliwych $i$ uznajacy oś polityczne-seksualne za wykluczająca się wzajemnie.
\end{abstract}

Stowa kluczowe: homoerotyzm, PRL, Juliusz Machulski, kamp

Od premiery Kingsajzu Juliusza Machulskiego mija równo 30 lat, a ja sam ostatni raz oglądałem go albo jeszcze w PRL-u, albo krótko po jego upadku. Od jakiegoś czasu zastanawiałem się, dlaczego w filmach i sztukach Machulskiego w zasadzie nigdy nie pojawiają się wątki czy postacie homoseksualne - podobnie jak zastanawiam się, czemu taki brak występuje w twórczości Woody'ego Allena. Tymczasem Kingsajz obejrzany po około trzech dekadach oraz licznych lekturach queerowych, cudzych i własnych, zaskoczył mnie obfitością homoerotycznych aluzji. Są to aluzje nieco może zakodowane, szczególnie dla ówczesnego odbiorcy, toteż podejmę próbę ich odszyfrowania; są to aluzje nieco może ornamentalne, ale takie ich nagromadzenie prowokuje mnie do odczytania ich jako budujących pewien bardziej zasadniczy kompleks wyobrażeniowy.

Zwyczajowo Kingsajz postrzegany jest jako dość prosta krytyka totalitaryzmu w jego aspekcie politycznym; w odczytaniu tym zwraca się uwagę raczej na to, że się zabrania, niż na to czego się zabrania. Moje odczytanie ma wskazywać nie tylko na subwersywne seksualne wątki w tym filmie, ale też dekonstruować dominującą fikcję poznawczą czy alegorię czytania tego rodzaju aluzyjnych dzieł w polskiej mentalności. W uproszczeniu chodzi o mechanizm uznawania prymatu polityczności nad

\footnotetext{
${ }^{1}$ Warto przyjrzeć się choćby wypowiedziom widzów na portalu Filmweb.pl. Użytkownik kinoman77_filmweb, wypowiedź o temacie "Znakomita antyutopijna komedia": "Genialna w swojej prostocie metafora komunizmu, na przykładzie Szuflandii vs. Kingsajzu”. Użytkownik Goro_Gondo, wypowiedź o tytule „Dobre”: „Kino w stylu >>Misia<< pokazujące komune w krzywym zwierciadle, wręcz ośmiesza" (zachowuję styl oryginału). Użytkownik polkain, wypowiedź o tytule "Zbyt oczywisty": „Wszystkie anty-systemowe alegorie są tak oczywiste i proste w odbiorze, że zastanawiam się czy w tym filmie jest cokolwiek więcej?". Użytkowniczka Valtara, wypowiedź o tytule „mialam 3 lata jak to widzialam 1 raz”: "ogolnie super komedia antykomunistyczna" (pisownia oryginalna). Użytkownik / użytkowniczka doorshlaq, wypowiedź o temacie "Małe dziełko": „Jedna z najśmieszniejszych i najcelniejszych komedii antykomunistycznych obok $>>$ Misia $<<$ czy > > Seksmisji<< „. Użytkownik Rockmen, wypowiedź o temacie "Dopiero teraz...": „Zrozumiałem ze ten film odnosi się o czasów PRL” (pisownia oryginalna). Użytkowniczka soowkax78, wypowiedź o temacie „świetny!!!”: „fantastycznie zrobiona, inteligentna i dowcipna satyra na PRL w znakomitej obsadzie, ze świetnym aktorstwem i bardzo przyjemną ścieżką dźwiękową". Użytkownik / użytkowniczka Maat, wypowiedź o temacie "jedna z najlepszych polskich komedii": "Świetna parodia systemu PRL..... a teksty genialne!!”. Żadna z wypowiedzi nie odnosi się do kwestii queerowych. Jedyne, które można uznać za jakkolwiek dostrzegające problem genderowy, to zdziwienie, że postać Bombaliny gra Witold Pyrkosz a nie aktorka, oraz konstatacja, że w Seksmisji był świat bez mężczyzn, a w Szuflandii jest świat bez kobiet. (Filmweb Forum).
} 
innymi aspektami (tu nad seksualnością), czy uznawania wszelkich aspektów (tu seksualności) za "tylko" metaforę polityczności, co ostatecznie ruguje te pozostałe aspekty (tu seksualność). Mechanizm ten powoduje, że dzieło "nie może” dotyczyć zarówno polityczności jak i seksualności, jeśli uznawać je za rozłączne, a w jeszcze mniejszym stopniu polityczności jako seksualnej i seksualności jako politycznej. Wyjątkiem mogą być najbardziej konwencjonalne heteroerotyczne fabuły romansowe, mogące działać - mówię nie o zamyśle twórczym a dominującym kodzie tzw. straight reader jak soczewka skupiająca całą uwagę na takiej najbardziej konwencjonalnej reprezentacji romansu z ewentualnym lekkim pieprzykiem (np. w Kingsajzie pamiętna i pomysłowa scena z pomniejszonym Olem i śpiącą Alą), przez co "marginesy” romansowe oraz erotyczne przestają być dostrzegalne. Podobnym tropem szły moje odczytania wskazujące na homoerotyczny kontekst szafy w Miłoszowej analizie "Ketmanu" czy skutki zmiany gestaltu w czytaniu Ciemności kryją ziemię Andrzejewskiego z alegorii stalinizmu na powieść gotycką o homoerotyzmie i jego prześladowaniu. Dominująca fikcja poznawcza zakłada, że Miłosz używa pojęcia "ketman” wyłącznie po to, by mówić o dysydenctwie politycznym - jakkolwiek zaznacza on, że przeszczepia to pojęcie z kultury perskiej, gdzie dotyczyło orto- i heterodoksji religijnej, a zatem pojęcie to już u Miłosza było używane jako metafora, choć metafora dobrze osadzona w kompleksie analiz traktujących komunizm i socjalizm jako paralelne bądź substytucyjne względem chrześcijaństwa, jako nową religię bez boga; natomiast w moim odczytaniu eksponowałem luźne uwagi Miłosza dotyczące np. tego, jak kolor odzieży może być odebrany jako polityczny i przeto piętnujący, co prowadziło mnie do hipotezy, że pojęcie "ketman" może wchodzić nie tylko w relacje wymienności metaforycznej religijność-polityczność (można przyjąć, że tertium comparationis staje się tu pojęcie "ideologia"), ale także z pojęciem "(ukrywana) seksualność". Moją hipotezę wspierał fakt, że rozdział Zniewolonego umysłu pt. „Alfa” poświęcony jest jednemu z najbliższych przyjaciół Miłosza, Jerzemu Andrzejewskiemu, który nie był skądinąd jedynym znanym Miłoszowi gejem negocjującym swoją "szafę" gdzieś między przestrzenią prywatną a publiczną (Miłosz w zasadzie był otoczony przyjaciółmi-gejami, by pobieżnie wskazać Czechowicza, Napierskiego, Iwaszkiewicza, Gombrowicza, Giedroycia). Miłosz obserwował „ketman seksualny”, by tak rzec - czyli szafę - jeszcze w latach 30., a więc wcześniej niż mógł zaobserwować "ketman polityczny", jakkolwiek w dominującej polskiej fikcji poznawczej "ketman” utożsamiono z politycznością (Sobolczyk 2015). Podobną zmianę gestalt zaproponowałem w lekturze powieści rzeczonego Andrzejewskiego, gdzie metaforę Hiszpanii średniowiecznej pod rządami inkwizycji odczytywano wyłącznie jako alegorię stalinizmu, ewentualnie dostrzegając analogie w prześladowaniu Żydów pod rządami królów katolickich z doświadczeniem Zagłady w XX wieku. Tymczasem jeśli uznać, że nie jest to "udawana powieść historyczna” będąca "tak naprawdę" parabolą, zaś że jest to powieść gotycka inspirowana angielskimi klasycznymi powieściami z przełomu XVIII i XIX wieku (np. Mnich Matthew Gregory'ego Lewisa, Italczyk Ann Radcliffe, Zofloya Charlotty Dacre i przede wszystkim Melmoth Charlesa Maturina - wszystkie ukazujące horrors of catholicism wedle formuły badacza queer gothic, George'a Haggerty'ego), Ciemności kryją ziemię okazują się powieścią o jakimkolwiek totalitaryzmie, w tym religijnym, a fakt, że w powieści nie ma bohaterów innych niż mężczyźni tworzący "niewypowiadalne" układy partnerstwa, oraz opis zamku noszącego się na czerwono ( zz mauretańska”) dysydenta - pozwalają odczytać tę powieść także jako traktującą o nienormatywnej seksualności w 
czasach paranoi (Sobolczyk 2017). Wyzyskując podobny gest zmiany gestaltu można przepatrzeć także inne polskie utwory postrzegane w świetle dominującej fikcji poznawczej jako prymarnie polityczne. Choćby Barwy ochronne Krzysztofa Zanussiego. W niniejszym eseju w takiej matrycy spróbuję usytuować Kingsajz, zbierając i interpretując liczne mikroaluzje.

Pomocne będzie w tym także rozpoznanie Kevina Mossa. Opisywał on różnicę między zachodnim a komunistycznym i postkomunistycznym myśleniem o seksualności, wskazując, że analogiczne metafory poznawcze używane są do opisu dysydenctwa politycznego (w kulturach sowieckich) i homoseksualności (na Zachodzie):

We wschodnioeuropejskich kulturach w czasach sowieckich główna oś strukturyzująca myślenie nie jest seksualna, ale polityczna: dysydencki / prosowiecki. Może być uzasadnione rozważanie jak inne definicje mniejszości / większości (rasowe, etniczne, płciowe i inne) funkcjonują podobnie lub odmiennie, bądź przecinają się w złożony sposób, jest przynajmniej jedno podobieństwo pomiędzy dysydenctwem seksualnym i politycznym, które różni je od pozostałych: w większości wypadków nie są one natychmiast widoczne, nie są - jak na ogół rasa, etniczność i płeć - niezmiennie przypisane od urodzenia. Sytuacja ta wysuwa na plan pierwszy problem wiedzy / niewiedzy w tych kategoriach (seksualność, dysydenctwo polityczne) w sposób odmienny od pozostałych kategorii. Przymusowy heteroseksizm i przymusowa ortodoksja polityczna wymuszają na dysydentach seksualnych i politycznych ukrywanie swej dysydenckości. Wykażę, że środki wyzyskiwane na Zachodzie do ukrywania dysydenctwa seksualnego, do konstrukcji szafy, często są identyczne jak te używane w Europie Wschodniej do ukrywania dysydenctwa politycznego (Moss 1995: 229-230). ${ }^{2}$

Nie można jednak poprzestać na konstatacji, że występuje tego rodzaju podobieństwo, ponieważ dysydenci polityczni występują także w niekomunistycznych społeczeństwach zachodnich (choć znaczy to coś zupełnie innego niż w krajach totalitarnych), jak też dysydenci seksualni (homoseksualni, transpłciowi...) występują w społeczeństwach totalitarnych i używanie tych samych środków ekspresji oznacza w innym kontekście zupełnie co innego, a przede wszystkim dysydenctwo polityczne i seksualne może się nakładać w różnym stopniu, co skutkuje złożoną grą luster, przemilczeń, aluzji. Postaram się pokazać, że Machulskiemu w Kingsajzie udało się poprowadzić owe złożone gry w lekki, acz dla większości mało czytelny sposób. 30 lat po premierze Kingsajzu może nastał moment, by na nowo przemyśleć, czym była - i czym nie była - polityczna walka w latach 80., i jaką rolę wówczas odgrywała - a jakiej często nie odgrywała - artystyczna satyra. Akcent kładę na możliwość odczytania wbrew dominującej fikcji poznawczej, wbrew kodowi straight reader, a to naraża na zarzuty,

\footnotetext{
${ }^{2}$ Moss nawiązuje tu do aparatu pojęciowego Eve Kosofsky Sedgwick (teza o tym, że kultury zachodniej nie da się zrozumieć bez osi hetero-homoseksualność a także para pojęć „uniwersalizujące / mniejszościujące”).
} 
że idę wbrew intencji autora, tj. Machulskiego. W istocie chodzi mi głównie o przetestowanie czym Kingsajz może być w oku queer reader, powtarzając modelowe pytania, jakie zdaniem Eve Kosofky Sedgwick stawia kamp:

Inaczej niż w wypadku atrybucji kiczu, system rozpoznawania kampu nie pyta: „Jaka zdegenerowana istota mogłaby być odpowiednią widownią dla tego spektaklu?" Zamiast tego pyta a gdyby / a jeśli: „A jeśli odpowiednią publicznością byłbym właśnie ja?" A gdyby na przykład oporne, ukośne, niebezpośrednie "inwestowanie" uwagi i przyjemności, które jestem zdolny wnieść do tego spektaklu, naprawdę przystawało do opornej, ukośnej, niebezpośredniej „inwestycji” człowieka, czy też ludzi, którzy go stworzyli? A co by było, idźmy dalej, gdyby inni ludzie, których nie znam czy nie rozpoznaję, mogli ów spektakl oglądać z tej samej "perwersyjnej” perspektywy? (Sedgwick 2012: 523).

Jeśli ktoś chce, może uznać moja lekturę za "kampowanie”, choć muszę zaznaczyć, że nie jest to procedura tożsama z uznaniem czegoś za kamp (według mnie Kingsajz nie jest kampowy, choć niektóre sceny są kampowi bliskie). W finale eseju postaram się także nieco inaczej usytuować pytanie „a co jeśli”, dopytując o jednak możliwą intencję Machulskiego, jakkolwiek odpowiedź z konieczności pozostanie tylko hipotezą.

Wyliczmy zatem te liczne mikroaluzje, które dostrzegłem oglądając Kingsajz "nowym okiem". Najoczywistsza jest tu postać pojawiająca się dosłownie na kilka sekund i nieodnotowana nawet w napisach ani w obsadzie filmu podanej w bazie filmpolski.pl - reżysera (czy asystenta) pokazu mody (na widok Ola pytającego bez entuzjazmu Ewę "co to za model”), którego epizod poprowadzony jest według stereotypu gejowskiej (nie)męskości związanej ze światem mody. Dalej tropem wyobrażeń stereotypowych zastanawiająca jest oczywiście postać Zenony (Zenona?) Bombaliny, redaktor naczelnej „Pasikonika”, granej przez Witolda Pyrkosza. Z jednej strony to aluzja do finalnego dénouement Seksmisji (a Kingsajz jest pełen aluzji do wcześniejszych filmów Machulskiego), z drugiej może aluzja do Poszukiwany / poszukiwana Barei, z trzeciej klasyczna tzw. high het entertainment (heterycka rozrywka), tj. śmiech z chłopa przebranego za babę (Butler 1993: 126). Jednak Bombalina i jej gender zostają wmieszane w bardziej skomplikowane gry. W świecie "kingsajzu”, tj. plus-minus w PRLowskiej Warszawie, Olo zawsze mówi o Bombalinie jako o kobiecie, ale przyparty do muru w Szuflandii, chcąc ratować Adasia, wymieni Zenona Bombalinę jako zadekowanego krasnoludka, właściwego odkrywcę formuły eliksiru kingsajzu - a agenci reżimu stwierdzają, że istnieje taka osoba i imię oraz nazwisko się zgadzają. Oczywiście gdyby Bombalina miała pierwotnie tożsamość krasnoludka, nie mogłaby być kobietą, bo krasnoludków żeńskich po prostu nie ma. Ale może Bombalina faktycznie jest / był kransoludkiem? Tak rozwikłana przeze mnie aluzja okazuje się teraz całkiem czytelna w kontekście czy transpłciowości, czy transwestytyzmu. Układ światów możliwych w filmie na planie politycznym trzeba czytać według takiego na ogół schematu: Szuflandia reprezentuje (upraszczając) 
PRL, zaś PRL-owska Warszawa czy cała Polska reprezentuje tu świat pożądany, a więc tzw. Zachód. ${ }^{3}$ Taka konstrukcja była niezbędna Machulskiemu, aby mógł przekonywać cenzorów, iż jego film nie jest satyrą na socjalizm. Innymi słowy, ekspresja (płciowa), która nie jest możliwa w świecie dyktatury, staje się potencjalnością w świecie pożądanym. Jest i trzecia postać wykreowana "po stereotypie”, choć to akurat może się okazać dla wielu teza kontrowersyjna - stroje i stylizacja cielesna katów w Szuflandii przypominają mianowicie "gejów z klubu dla skórzaków", czy z klubu S/M, powiedzmy - z Cruising Williama Friedkina, co w latach 80. stało się nowym i nierzadko komediowym chwytemskrótem reprezentacji (nie?)męskości gejowskiej - wystarczy wspomnieć klub Błękitna Ostryga w Akademii Policyjnej (Savran 1998: 213-219).

Całkiem sporo jest także wypowiedzi i zachowań krasnoludków, które zdają się sygnalizować, że w ich świecie pewną siłą motoryczną jest sublimowany homoerotyzm, albo raczej napięcie homoerotyczne / homospołeczne. Podałem tezę interpretacyjną zanim wskazałem przykłady, ale tezę tę przyjdzie mi jeszcze pogłębić. Scena, w której Olo, Kwintek i Kramerko mają przeniknąć do Szuflandii okazała się po latach czytelnie homoerotyczna być może nie tylko dla mnie - dowodem parodystyczny amatorski filmik na Youtubie. ${ }^{4}$ Dwaj bohaterowie rozbierają się do bielizny i nakazują to samo trzeciemu. Istotna jest tu choreografia sceny. Kwintek i Kramerko stają dokładnie naprzeciwko siebie i to bardzo blisko (celowo więc są filmowani z bliskiego planu) i zaczynają się w takiej właśnie pozycji rozbierać po znaczącym skinieniu głową jednego z nich. Kamera zjeżdża na Ola, który patrzy z przerażeniem, a po chwili spuszcza wzrok. Kiedy słyszy rozkaz "rozbieraj się!", odwraca się do Kwintka i Kramerki (skaczących i skandujących "raz - dwa - trzy - raz - dwa - trzy!") tyłem. Tu następuje przebitka do kolejnej sceny, która tylko wzmacnia homoerotyczny przekaz: bohaterowie będą sobie wstrzykiwać eliksir pomniejszający strzykawką - tj. robić zastrzyk w pośladek. Kramerko (pokazywany w zbliżeniu na twarz) powtarza "nie lubię, nie lubię" i zaciska pośladki aż igła się wygina, a Kwintek instruuje go "rozluźnij muskułę” (celowa agramatyczność, zmiana rodzaju męskiego "muskuł" na „muskuła” odsyła do bardziej potocznego "rozluźnij dupę”). Wówczas Olo stwierdza: „mam nadzieję, że to jednorazówka, tyle się teraz mówi o AIDS". Kwintek wbija mu igłę w ramię (zatem są różne muskuły, w które można płyn wstrzyknąć). Strzykawka z igłą kondensuje tu dwa najbardziej zasadnicze fantazmaty o AIDS w latach 80., narkomanię i seks analny (nie trzeba uruchamiać psychoanalizy, by we wbijaniu igły, osobliwie w tyłek, dostrzec metaforę penetracyjną). ${ }^{5}$ Kolejne dwie aluzje słowno-

\footnotetext{
${ }^{3}$ Podobnie uważa Tomasz Basiuk (Basiuk 2011: 474-475). Badacz sytuuje Kingsajz jako poboczny kontekst w interpretacji prac fotograficznych Ryszarda Kisiela, twórcy zinu "Filo", oraz w kontekście akcji "Hiacynt” i "różowych teczek".

${ }^{4}$ Dwóch chłopaków staje naprzeciwko siebie i zaczyna się rozbierać do majtek, po czym zerkają w kamerę i mówią „rozbieraj się!” (Juras715764 2011). Jednak i ten filmik może budzić rozbieżne interpretacje -w recenzji niniejszego artykułu Autor(ka) wskazał(a), że nie odbiera go jako sugerującego homoerotyzm - ja zaś tak odbieram. Nie idzie oczywiście o to, że ktoś ma rację, bo nie idzie o to, że ktoś może mieć rację w tej kwestii. Dla mnie powód zrobienia tego filmiku jest zupełnie nieoczywisty, jeśli przyjąć, że nie sugeruje on homoerotyzmu oryginalnej sceny w Kingsajzie. Z drugiej strony mógłbym kontrargumentować wbrew swojemu odczytaniu a wspierając recenzenckie, że po pierwsze ludzie publikują w YouTube różne materiały bez ambicji zakomunikowania czegokolwiek, a dla tzw. „beki”, a po drugie, sam wskazywałem wyżej kilkanaście wypowiedzi widzów z forum Filmweb, gdzie nikt nie dostrzegał w filmie wątków homoerotycznych.

${ }^{5}$ Miejmy też w pamięci ważkie stwierdzenie badaczki queerowej literatury nt. AIDS: „Posiadanie AIDS może nie czyni cię homoseksualnym, natomiast owszem czyniło cię queerowym (...) nie chodzi tylko o to, że AIDS czyni kogoś queerowym,
} 
choreograficzne związane są z postacią dyktatora nadszyszkownika Kilkujadka, granego przez Jerzego Stuhra (powie ktoś, że przesadzam, ale może to nieprzypadkowe skojarzenie: "kilkuzadek"). Pierwsza scena, chyba czysto ornamentacyjna, to zatrzaśnięty przez Ola w saunie - czajniku (czyżby aluzja do sekwencji Snu o siedmiu szklankach w Akademii Pana Kleksa, gdzie skądinąd Pan Kleks występuje właśnie w postaci „krasnoludzkiej”?) Kilkujadek. Jego totumfaccy próbują go uwolnić przy pomocy pił, a on krzyczy „rżniesz mnie! rżniesz mnie!”, na co agent: „tak jest!”. Wreszcie scena najbliższa może kampowi, w której Kilkujadek i dwóch jego agentów w bieliźnie gonią Ola po łazience. Olowi udaje się wskoczyć na sznurek do spuszczania wody, ścigający go wskakują za nim, Kilkujadek pierwszy. Dyktator sięga ręką w górę, chcąc pochwycić Ola, ale udaje mu się tylko zsunąć jego majtki. Przez kilkanaście sekund widzimy nagi pośladek bohatera, a dyktator wykrzykuje, szarpiąc za majtki: „teraz jesteś mój! mój będziesz, tylko mój!” Jak pamiętamy, dyktator i jego ludzie lądują w wodach (?) klozetu, "gdzie ich miejsce". Oprócz innych, bardziej oczywistych skojarzeń, uruchomione tu zostaje i takie, w latach 80. dużo częstsze niż obecnie, z "kloaczną homoseksualnością".

Pora na drobną dawkę klasycznej psychoanalizy. Bruno Bettelheim o krasnoludkach powiada, że „zatrzymały się na zawsze w preedypalnej fazie rozwojowej, nie osiągnąwszy dojrzałego człowieczeństwa (nie mają one rodziców, ale nie zawierają też małżeństw i nie mają dzieci)" (Bettelheim 1985: 70). ${ }^{6}$ I dalej:

Nie ma krasnoludków płci żeńskiej. (...) są zawsze i tylko - a więc z istoty swojej postaciami męskimi, lecz jednocześnie są to postacie zahamowane w rozwoju. (...) przywodzą na myśl skojarzenia falliczne. Na pewno nie są to mężczyźni w seksual.nym znaczeniu słowa, gdy właściwy im sposób życia, wyłączne zainteresowanie dobrami materialnymi i wykluczenie miłości wskazują na trwanie w stadium preedypalnym (Bettelheim 1985: 86-87).

Uzupełnijmy, że mali bohaterowie Szuflandii nie są zainteresowani dobrami materialnymi, a władzą jako kontrolą i wolnością (dysydenci), ale poza tym wszystko się zgadza. Konflikt władza - wolność Machulski przedstawia właśnie w kategoriach seksualnych. Pamiętna wypowiedź Kilkujadka to potwierdza: „Ja wam tak szczerze, po krasnoludzku, teraz powiem. Wiecie, co ich tak naprawdę ciągnie do Kingsajzu, bardziej niż te wszystkie szlachetne słowa? Kobitki! Ciurlać się chcą z nimi, o!" Innymi słowy, Kingsajz teoretycznie doprowadza do edypalizacji (ergo seksualizacji) krasnoludków, sprawowanie kontroli zaś polega na utrzymywaniu ich w stadium preedypalnym. Machulski robi tu jednak kilka przewrotek: po pierwsze owo stadium preedypalne nie jest, jak już wskazywałem, tak

ale o skojarzenie tej choroby z tożsamością seksualną i zarazem, jak jest w wypadku AIDS (albo jak AIDS jest wyobrażane), jako zarówno chroniczne i dające się zarządzać" (Pearl 2012: 59). W ustach Ola lęk przed strzykawką / AIDS (i używającymi strzykawki niezedypalizowanymi powiększonymi kransoludkami) oznacza zatem lęk przed zahamowaniem jego edypalizacji wskutek "ukąszenia”, co nadałoby mu - na powrót - i zafiksowało tożsamość "queerową" postrzeganą jako taka w obu światach.

${ }^{6}$ Zbieżność daty wydania przekładu tej pracy i powstania Kingsajzu pozwala zasugerować nieśmiało, że Machulski mógł się zainspirować Bettelheimem. Postać Ali (Katarzyna Figura) także wydaje się przepisaną Królewną Śnieżką. 
całkiem nieerotyczne, jest podszytem homoerotyzmem (homospołecznym) i marzeniem o desublimacji (idącej w różnych kierunkach). Po drugie różnie z tą edypalizacją. Sam Kilkujadek, często przebywający w Kingsajzie, otoczony jest „kobitkami” (scena pokazu mody), co oczywiście pokazuje niekonsekwencję władzy zakazującej, podobnie jak finał Seksmisji. Zedypalizował się Olo, ma narzeczoną Ewę, choć ciągnie go też do Ali. Ale już Adaś na wolności zajmował się wyłącznie chemią (to znaczy poszukiwaniem eliksiru kingsajzu, a zatem wolnością dla wszystkich). Ale czy jego stosunek do Ola nie jest przesublimowanym homoerotyzmem? Albo w każdym razie pozostaniem w aseksualności? Alternatywną drogę wobec edypalizacji wybrała też Bombalina (jeśli założyć, że była krasnoludkiem). Z kolei jeśli zupełnie dosłownie odczytać postaci Kwintka i Kramerki, okazuje się, że na wolności albo wybrali oni nieklasyczny wariant edypalizacji (tj. nakierowany nie na matkę, a na ojca), albo najpewniej jednak zdesublimowali fraternalność krasnoludzką i Kingsajz zmienili w swój prywatny "pinksajz”.

Co najmniej cztery sceny pokazują na latentnie homoerotyczny charakter kondycji krasnoludzkiej. Dwie z nich stanowią w zasadzie powtórzenie wyznania Ola, brzmiącego zupełnie jak coming out osoby homoseksualnej. Najpierw zostaje on dokonany przed Ewą, a potem przed Alą, ale ta przełamuje konwencję i sama odgaduje w Olu krasnoludka. Oto jak brzmi ten performatyw:

Olo: Ja ci muszę coś powiedzieć!

Ewa: Musisz mi coś powiedzieć? Nareszcie.

Olo: Ja jeszcze nikomu o tym nie mówiłem.

Ewa: Żadnej kobiecie?

Olo: Żadnej. Ale obiecaj, że nie będziesz się śmiać.

Ewa: Nie będę.

Olo: Ja... Ja... Ja nie wiem jak ci to powiedzieć, ale... Ja jestem... Ja jestem krasnoludkiem.

Ewa: To mają być oświadczyny? ${ }^{7}$

Pisząc o wątkach homoerotycznych w Kajtusiu czarodzieju Janusza Korczaka zwróciłem uwagę na analogiczną formułę „wiedzy / ujawnienia” jako możliwej metafory homoseksualności (czy seksual.ności nienormatywnej w każdym razie) w dyskursie o „czarodziejach”. Koledzy z klasy nazwali Kajtusia czarodziejem, wiedzieli to przed nim, rozpoznali go; i faktycznie jest czarodziejem, rozpoczyna życie z taką tożsamością. Olo także w pracy zawodowej tj. jako dziennikarz pisze artykuły o krasnoludkach, ale tak jakby jego samego to nie dotyczyło, a pewne informacje przez niego podawane są przez innych traktowane dość paranoidalnie (wymysły albo przejaw choroby psychicznej): tak też brzmiały pierwsze polskie teksty prasowe o homoseksualności (choćby Mariusza Szczygła). Wreszcie dziwna

\footnotetext{
${ }^{7}$ Por. też relację Ola Ewie z wydarzeń wieczoru, gdy musiał ją zostawić w mieszkaniu aby ratować Adasia: „najpierw byłem w hotelu i tam spotkałem jedną panią i poszedłem do niej. Potem poszedłem do pracowni Adasia i tam spotkałem dwóch panów. A na dachu był kot. Więc spadłem na ziemię no i już jestem z powrotem." Ewa widzi zagrożenie tylko we frazie "spotkałem jedną panią", ale przecież fraza "spotkałem dwóch panów" jest wobec niej paralelna.
} 
scena na bazarze, w której Olo przebrany za Mikołaja (tj. w spódnicy Ewy robiącej za pelerynę) próbuje znaleźć kontakt do utajonych (żyjących w ukryciu) krasnoludków. Chodzi między ludźmi szepcząc "Szuflandia, Szuflandia... szuflada, szuflada...", na co pewien mężczyzna uderza go, krzycząc „zboczeńcu! zwyrodnialcu ty!”. Po pierwsze więc przynajmniej część ludzi w świecie Kingsajzu identyfikuje "kransoludzkość" ze „zboczeniem” (a więc jeśli nie jakimś fetyszyzmem, to z homoseksualnością); po drugie, scena ta parodiuje gejowski cruising, tyle że w biały dzień (poszukiwanie "swoich"); po trzecie, "szuflada" nabiera znaczenia "szafa”. ${ }^{8}$ O znaczeniu tym w latach 80. z pewnością nie wiedziało w Polsce wielu, ale Machulski mógłje poznać na Zachodzie. W późniejszej o dwa lata komedii Co lubią tygrysy? Krzysztofa Nowaka porzucony przez żonę Piotr (Wojciech Pokora) jedzie z kolegą Markiem do Sopotu aby oderwać się od ponurych myśli i zapoznać nowe kobiety; po szeregu nieudanych spotkań w pokoju hotelowym odwiedza go poznana na plaży i wyzywana (m.in. od „parów”) postać mówiąca o sobie w rodzaju żeńskim, ale będąca mężczyzną (w samym filmie nikt się tak do niej nie zwraca, ale w napisach końcowych określona jest jako „Bisex"), o czym Piotr bodaj nie wie - post factum Marek znajduje go zszokowanego zamkniętego w szafie. I sądzę, że owa szafa jest tu "sekretnym kodem" (Sobolczyk 2012). ${ }^{9}$ Myślę, że metafora szuflada - szafa ${ }^{10}$ obecna jest też w tekście piosenki słyszanej podczas pokazu mody (wykonanie: Mieczysław Szcześniak, Anna Jurksztowicz i Majka Jeżowska, tekst Juliusz Machulski, muzyka Krzesimir Dębski): „gdy duszy duszno / w szufladzie ciała / a wokół ciebie tyle łajz / dopóki dusza jeszcze cała / wyłaź z szuflady / wyłaź z szuflady / wyłaź z szuflady / przejdź / Kingsajz to raj / gdzie wszystko naj / to seks, to luz / to utracony raj". Słyszymy tu echo nie tylko chrześcijańskiej koncepcji „duszy uwięzionej w ciele”, ale też wczesnodwudziestowiecznych konceptualizacji homoseksualności męskiej (np. Magnusa Hirshfelda) jako "kobiecej duszy uwięzionej w męskim ciele” (Steakley 1997: 142) - czyli kingsajzowej duszy uwięzionej w ciele krasnoludzkim. Krasnoludki wydają się dobrą metaforą homoseksualności, ponieważ ta jest najczęściej niewidoczna, niewyczytywalna z ciała, choć można ją uczynić widoczną. Czyni ją widoczną asystent przy spektaklu modowym, ale już Adaś? (Zakładając na chwilę, że kieruje swe sympatie ku mężczyznom, np. Olowi). Krasnoludzkie ciało jest takie samo w wersji mini i maxi, zmienia się tylko układ proporcji, perspektywa, soczewka. Taki gestalt switch dokonuje się nierzadko również w wypadku bycia świadkiem ujawnienia się osoby homoseksualnej czy transpłciowej („aha, te dziwne zachowania oznaczały to i tamto!"); dlatego możliwe jest odczytanie sceny wyznania Ola Ewie tożsa-

\footnotetext{
${ }^{8}$ Choć możliwe do pomyślenia także jest skojarzenie z aktami służb specjalnych, np. „różowymi teczkami” z Akcji "Hiacynt", ale ogóle z teczkami i archiwizowaniem donosów jako elementem aparatu kontroli w dyktaturze.

9 Jest to dość polemiczna recenzja książki Gejerel Krzysztofa Tomasika (Tomasik 2012), gdzie autor omawia m.in. motywy LGBT w kinie polskim okresu PRL-u, ale nie wspomina o Co lubia tygrysy i kilku innych filmach, o które się w recenzji upominam.

10 Lingwistycznie jest to oparte na mechanizmie synekdochy (szuflada to część szafy). Gra ta wpisuje się w logikę odkształceń słownych (czy nowomowy wręcz) krasnoludków, którą, jak się zdaje, publiczność pokochała i uznała za kultową. Chodzi o wyrażenia typu "ty smrolu!" - odkształcone "ty śmierdzielu” z kontaminacją "smród” czy "smrodek" i "troll”; "ciurlać się” (z kobitkami) - jak "ciupciać” (nie jestem pewny, ale wydaje mi się, że Machulski wymyślił to słowo, a dopiero później powstało slangowe wyrażenie "ciurlać dropsa" oznaczające seks oralny wykonywany na penisie; podobnie, jak mi się wydaje, polszczyzna potoczna zawdzięcza Kingsajzowi szeroko używany obecnie skrótowiec "spoko"); „w dziuplę kopany" jak „w dupę kopany” (albo wręcz „w dupę j...ny”); „kumotrze” jak „towarzyszu”, ale z pobrzmiewającym echem "łotrze" (łączonym z "kumem”). Do grupy takich odkształceń należy także powtarzane jako wyraz niepokoju i alarmu „hejkum kejkum” (niczym angielskie „mayday”).
} 
mości krasnoludzkiej jako homoseksualnej. Nawet i pozostałe konsekwencje kingsajzowej metafory w jakiejś mierze się zgadzają - krasnoludki, jak wiadomo, aby pozostać w kondycji kingsajzowej, muszą regularnie pić Polo-coctę. Jest to napój autentycznie sprzedawany w PRL-u, ale nadanie mu charakteru mitycznego kojarzy się z mitologizacją Pepsi czy Coca-coli (normatywnie negatywną w intencji władz ludowych, a fetyszystycznie pozytywną w oczach spragnionych konsumentów), co skądinąd zapewne odsyła do socrealistycznych ataków, gdy Coca-colę nazywano stonką ziemniaczaną w płynie, a także do Pieśni o coca-cola Adama Ważyka, por.: „Po coca-cola błogo, różowo (...) my wam przerwiemy sen coca-cola, / my, co pijemy wodę nadziei"), co można zrozumieć jako stały wysiłek w performowaniu własnego ciała, aby wyglądało na "męskie, heteroseksualne”.

Odpowiedź na pytanie, dlaczego Machulski zdecydował się stworzyć tak gęstą, a przeto konsekwentną sieć aluzji homoerotycznych, musi być złożona. Po pierwsze emancypacja seksualna jako taka, a totalitaryzm przestawiony jest tu jako represja i tabuizacja seksualności właśnie, jest zasadniczą właściwością czy wartością świata pożądanego, świata, do którego się dąży, czyli, po odrzuceniu alegorii - świata Zachodu. Jeśli ktoś znał nieco świat Zachodu w latach 80. i rozważał kwestie emancypacji seksualności, to nie mógł nie dostrzec emancypacji kobiet, ale też mniejszości seksualnych. Innymi słowy Machulski zdaje się mówić „emancypacja nie podąża tylko wąską edypalną ścieżką” (tj. heteroseksualną), musi być szeroka; „kingsajz dla wszystkich”. Wszystkich. Przesłanie takie, o ile ktoś w latach 80. w Polsce był w stanie je odczytać, musiało się zdawać zupełnie zdumiewające, ale z pewnością miałoby walor edukacyjny (a nawet i dziś może mieć: dążyliście w walce politycznej do świata wartości Zachodu, to czemu próbowaliście / próbujecie być selektywni w zakresie wartości tego świata akurat związanych z seksualnością). Po drugie być może Machulski dokonuje pewnej autokorekty na planie, by tak rzec, polityki genderowej - korekty w stosunku do Seksmisji. Oczywiście wiem, że w tej chwili myślę achronologicznie i krytyka ze strony feministek polskich i zachodnich, a nie twierdzę, że nieuzasadniona, przyszła później. Kingsajz właściwie mógłby mieć podobnie "konserwatywne" przesłanie jak Seksmisja (w uproszczeniu - klasyczna lękowa fantazja męska przed "zębatą waginą", która wygryzła ze świata mężczyzn, na co najlepszą receptą okazuje się odtworzenie dawnego porządku z tzw. tradycyjnym podziałem płci): źle sublimujące swoje homoerotyczne uczucia kransoludki w świecie Kingsajzu edypalizują się i wiążą z kobietami. Być może część odbiorców tak ten film też odczytuje, ponieważ jedną z zasadniczych osi filmu jest fabuła romansowa (Ola z Alą). Jednak omówione przeze mnie wyżej wątki Adasia, Bombaliny i Kwintka wraz z Kramerką wskazują na to, że heteroedypalizacja nie jest jedyną drogą w świecie pożądanym / świecie pożądania. Być może jednak sam Machulski uznał, że przesłanie Seksmisji nie jest w pełni satysfakcjonujące, czy też domaga się uzupełnienia, a może jakieś doświadczenia zachodnie mu to uświadomiły, choć to rzecz prosta tylko spekulacje. Rzec można, że różnica między tymi dwoma filmami przebiega też według logiki przejścia od płci (gender) ku seksualności. Po trzecie być może Machulski odnosił się jednak nie tylko do wartości świata Zachodu, przedstawianych tak, jakby były one obecne w PRL-u lat 80 . (zgodnie z logiką planów, wskazywaną przeze mnie wcześniej), ale też i do polskich doświadczeń z ekspresją homoseksualności. Równolegle z kręceniem Kingsajzu powstał Warszawski Ruch Homoseksualny, pierwsza emancypacyjna organizacja w Polsce, choć jej 
jeszcze bardziej nieformalne korzenie sięgają wcześniej, a mianowicie SBeckiej Akcji „Hiacynt”, rozpoczętej w 1985 r. (również mogącej mieć wpływ na kreację Szuflandii jako krainy represjonującej seksualność), i współpracy z austriacką organizacją HOSI. Struktura światów czy obiegów w ówczesnej Polsce jest w jakiejś mierze podobna do struktury światów w Kingsajzie. Pierwszy obieg w latach 80. to były publikacje oficjalne, drugi - to Solidarność; trzeci to inicjatywy młodsze i od Solidarności w swym etosie jednak różne, „Brulion”, Pomarańczowa Alternatywa (która przecież wyzyskiwała motyw krasnoludków...), anarchistyczny Ruch Społeczeństwa Alternatywnego w Trójmieście - i do tego obiegu należy przypisać też inicjatywy homoseksualne, w tym trzeciobiegowe pismo „Filo", fanzin publikowany od 1986 r. w Trójmieście. U Machulskiego: Szuflandia (czyli PRL), PRL jako Kingsajz (czyli niedoskonały Zachód, gdzie jednej strony obywatel w samie wspomni o ORMO, a z drugiej odbywają się szykowne pokazy mody), a finalna scena, tj. dziecko bawiące się miniaturową kolejką pod Pałacem Kultury, ujawnia kolejny poziom świata (tj. być może zwraca uwagę, że PRL-Kingsajz był światem jednak dość fantazmatycznym).

Na zakończenie proponuję zabawę, którą za Sedgwick można by nazwać "a gdyby / a jeśli”. Trzy wesołe krasnoludki Jana Brzechwy i ich przygody w "dużym świecie”. Kwaterko, Kwintek, Olo? Co czytelnik słyszy w takim cytacie? Zatańczyły też komary / Nie do pary i do pary, / Bo gdy dobra jest muzyka, / Komar tańczy i nie bzyka (Brzechwa 1959). Gdy tańczy, chowa strzykawkę?

\section{Bibliografia}

Basiuk, Tomasz. 2011. Uwagi na temat projektu "Kisieland" Karola Radziszewskiego. W: (red.) Pijarski K. The Archive As Project / Archiwum jako projekt. Warszawa: Fundacja Archeologii Fotografii, s. 460-481.

Bettelheim, Bruno. 1985. Cudowne i pożyteczne. T. 2. Danek, Danuta (tłum.). Warszawa: Państwowy Instytut Wydawniczy.

Brzechwa, Jan. 1959. Trzy wesołe krasnoludki. Warszawa: Czytelnik.

Butler, Judith. Bodies That Matter. On the Discursive Limits of "Sex". New York - London: Routledge.

Filmweb Forum, http://www.filmweb.pl/Kingsajz/discussion; dostęp: 3 IX 2017.

Juras 715764, 2011. Kingsajz Juliusz Machulski 1987.

https://www.youtube.com/watch?v=VS3zllo9wGg; dostęp: 11 VIII 2017.

Kosofsky Sedgwick, Eve. 2012. Wilde, Nietzsche i sentymentalne związki z męskim ciałem. Tłum.

Warkocki B. W: Czapliński P., Mizerka A. Kamp. Antologia przekładów. Kraków: Universitas, 503524.

Machulski, Juliusz, reż. 1987. Kingsajz. Polska, Zespół Filmowy Kadr.

Moss, Kevin. 1995. The Underground Closet: Political and Sexual Dissidence in Eastern Europe. W:

(red.) Berry, Ellen E. Genders 22. Postcommunism and the Body Politic. New York - London: New York University Press, s. 229-251.

Pearl, Monica B. 2012. AIDS Literature and Gay Identity. The Literature of Loss. New York - London: Routledge. 
Savran, David. 1998. Taking It Like a Man. White Masculinity, Masochism, and Contemporary American Culture. Princeton: Princeton University Press.

Sobolczyk, Piotr. 2012. GayRL czy QueeRL? W: „Teksty Drugie” 6, 119-128.

Sobolczyk, Piotr. 2017. Gotycyzm - modernistyczny sobowtór odmieńca. Gdańsk: Terytoria Książki.

Sobolczyk, Piotr. 2015. Polish Queer Modernism. Franfurt am Mein: Peter Lang Editions.

Steakley, James D. 1997. "Per Scienciam Ad Justitiam". Magnus Hirschfeld and the Sexual Politics of the Innate Homosexuality. W: (red.) Rosario, Vernon A. Science and Homosexualities. New York - London: Routledge, s. 133-154.

Tomasik, Krzysztof. 2012. Gejerel. Warszawa: Wydawnictwo Krytyki Politycznej.

\section{HEYKUM GAYKUM?}

By reinterpreting the Polish cult comedy Kingsajz (Kingsize, 1987), which is generally assumed to be a political allegory, this article argues that the film lends itself to a queer reading, as a statement on so-called regimes of gender. The author analyzes numerous homoerotic allusions in the film, and questions the dominant Polish reception code which privileges political interpretations over other possible readings, and which treats the political and the sexual as mutually exclusive.

Keywords: People's Republic of Poland, film, Juliusz Machulski, homoerotic allusions, camp 